The BDA -

\section{into the future}

Peter Ward

Chief Executive, BDA
Send your comments to the

Editor-in-Chief,

British Dental Journal

64 Wimpole Street,

London,

W1G 8YS

Email bdj@bda.org
This edition of the British Dental Journal heralds the beginning of a new era for the BDA and an opportunity for you to be central to its future direction. Within this mailing you will find the invitation to BDA members to be nominated as candidates to serve on the newly-created Principal Executive Committee (PEC) which will take up its duties in July of this year. You can also find details on-line at www.bda.org/pec. The PEC will replace the Representative Body and Executive Board as the main governing committee of the BDA. The members of the PEC will be directly elected by the BDA membership and will be the legally responsible directors of the Association.

It is a really important time to be involved. After six busy years of developing and modernising the BDA, the outgoing Executive Board and Representative Body leave the legacy of a highly-productive and member-focused organisation. The BDA has worked hard to establish an impressive track record of solid operational and financial management, coupled with high standards of customer service. The Association currently turns over about £16 million a year and holds reserves of about £1.7 million. We have recently invested in detailed member research in order to overhaul the BDA membership offering to tailor it better to the changing needs of modern dental professionals. The new PEC will inherit resources, reputation and research. It will take on the role of governance and stewardship of the Association and will oversee the next stage of its development.

\section{THE JOB OF A PEC MEMBER}

The BDA occupies a unique position within the UK dental landscape. It is owned entirely by the dentists who are its members and has the sole purpose of working in their interests both collectively and individually. It has no external shareholders and is a not-for-profit organisation. If fulfils a number of functions; it is a registered trade union, a professional membership organisation and an authoritative influencer on matters relating to dentistry in the UK. Although separate from the BDA, with separate trustees, within the BDA family is the BDA Trust which operates the museum and the library and oversees the allocation of grants from the Shirley Glasstone Hughes Research Fund. Most recently the trust benefited from the donation from the estate of the late John McLean and now administers the John McLean Archive. PEC members work closely with the trustees to ensure that both organisations work to best effect.

So from all of this it can be seen that the job of a PEC member will involve a diverse range of responsibilities and activities. But the most satisfying thing is the knowledge that every penny coming into the BDA (whether in the form of member subscriptions or from the sale of goods, products, services or events) goes back into the pool to work for BDA members. So the successfully elected members will also gain huge job satisfaction from the knowledge that they are working exclusively in the interests of their professional colleagues.

In the coming years, the pace of change in dentistry is only likely to accelerate and we will face a fundamentally different working environment for the dental team. The rapidly shifting NHS, changing roles of dental care professionals and the increasing necessity for competitive edge mean that if ever the profession needed proactive and visionary leadership it is now. Prospective candidates will be given the opportunity to steer the profession's fortune through this developing landscape and will be central to what the future holds. So this is not for the faint of heart or the unimaginative. The role will call for high energy committed individuals who really want to make a difference.

Has that whetted your appetite? Are you keen to get involved? If so, here is what's going to happen. The nomination process opens today the 24 March and will close at noon on the 23 April. Nominated candidates will have the opportunity to produce a written statement in support of their candidacy and will also be able to present themselves to prospective electors at the British Dental Conference and Exhibition in Manchester. To that end we have arranged 'speed-dating' type events on each of the three days of conference.

With the challenges facing the dental profession and the rapidly changing dental environment, this is a really important time for a new and energised PEC to pick up the baton from the highly committed outgoing body of directors. The work of the BDA demands that the successful process of regeneration that they have begun is continued with equal passion and commitment. The election process will ensure that the new PEC includes members from all corners of the United Kingdom. We are hoping that significant numbers of interested members put themselves forward to face the challenge of steering the dental profession's own organisation. With the service of dentists as our only mission and with members as our only financially-interested stakeholders, the BDA is truly the home of UK dentistry.

So if you are a BDA member and are passionate about the long-term sustainability and well-being of UK dentists and dentistry, why not throw your hat in the ring? Your profession needs you!

DOI: 10.1038/sj.bdj.2012.224 